\title{
O IMAGINÁRIO EM LYGIA BOJUNGA NUNES: TRADIÇÃO PEDAGÓGICA OU REINVENÇÃO DO GÊNERO?
}

Débora Aparecida Ianusz de Souza*

RESUMO:

O objetivo deste trabalho é analisar a produção literária de Lygia Bojunga Nunes, focalizando principalmente o espaço textual como lugar de construção de sentidos no qual alçamse o imaginário e outras possibilidades discursivas que configuram a escrita da autora. Procuro refletir sobre o estatuto da obra de Lygia Bojunga a fim de verificar em que medida seus textos romperiam com a tradição pedagógica dos livros para crianças, realçando a presença do imaginário.

PALAVRAS-CHAVE: imaginário, crianças, pedagógico, tradição, Lygia Bojunga Nunes.

Quando, em finais do século XVII, Charles Perrault publica Histories ou Contes du Temps Passé avec des Moralités, inicia-se a literatura destinada a crianças e postula-se um estilo que iria dirigir os textos infantis desde então: um didatismo que buscava moldar a criança segundo a perspectiva do adulto.

A concepção de criança baseava-se no pressuposto de que criança e adulto eram seres idênticos, diferenciando-se apenas quanto ao tamanho. A criança seria, portanto, um adulto em miniatura. Em meados do século XVII, inicia-se uma preocupação com o desenvolvimento psicológico e moral da criança, que passa a ser considerada um ser puro e inocente, e, por essa razão, deveria ser protegida da "impureza" do mundo adulto. Passa-se a investir na educação na tentativa de resguardar a criança em sua inocência e, ao mesmo tempo, banir sua "irracionalidade." 0 papel da escola, associado à literatura, é o de transformar seres considerados incapazes e frágeis em adultos perfeitos, além de incutir-lhes princípios morais que deveriam ser reproduzidos.

* Mestre em Letras: Estudos Literários (Área de concentração: Literatura Brasileira), 2000. 


\section{EM TESE}

Belo Horizonte, v. 5, p. I-305, dez. 2002

Esta concepção modificou-se através dos tempos. De adulto "menor", a criança passa a ser vista como um sujeito com direitos e deveres. Contudo, a literatura a ela destinada não sofreu grandes alterações. Ainda hoje, vemos textos que procuram apenas ensinar algo de útil às crianças. Essa literatura pedagógica difunde um discurso de dominação, prescreve valores, veicula modelos e vê a criança como um receptor passivo diante do texto ficcional. Entende-se, nesse sentido, que essa natureza didática impõe à literatura infantil a missão de transmitir ensinamentos, não a considerando em sua especificidade, além de não pensar questões como o real e o imaginário, uma vez que, ao apresentar essas categorias de forma dissociada, atribui à fantasia uma finalidade prática.

$\mathrm{Na}$ contemporaneidade, teóricos como Laura Sandroni acreditam que alguns autores rompem com essa tradição e propõem uma renovação da literatura, estando Lygia Bojunga Nunes dentre eles. Um dos motivos que fundamentam a avaliação de Laura Sandroni é, justamente, o novo tratamento dado pela escritora na abordagem do real e do fantástico:

Fundindo a fantasia com dados do real, Lygia Bojunga Nunes trabalha criticamente esses aspectos da vida e permite uma leitura vertical em vários níveis de compreensão. Ela adentra o mais profundo significado das coisas e apresentaas de forma metafórica possibilitando a reflexão e o entretenimento em perfeito equilíbrio. (SANDRONI, 1987: 88)

A visão mágica do mundo é característica da infância e o papel que a imaginação desempenha na vida da criança permite-1he dar vida ao inanimado e transfigurar a realidade. Segundo Jesualdo, a maior parte da vida da criança é ocupada por esse poder imaginativo,

embora por vezes sua evolução se retarde devido a causas orgânicas ou psicológicas, quando não pelo despropósito da educação que, em vez de dirigir ou estimular todo o impulso imaginativo da criança, coíbe e destrói qualquer indício de fantasia em sua vida. (JESUALDO, 1982: 77)

Ainda segundo Jesualdo, são vários os educadores que, em nome da verdade, procuraram banir o maravilhoso da vida da criança, impedindo a leitura de fábulas e contos por considerá-los um artifício para iludir a mente infantil.

Como na literatura infantil predomina a ótica do adulto; os textos, em sua maioria, giram em torno do monopólio da fala de um narrador onisciente que está 
sempre pronto a ensinar. Assim, o texto reverte-se, para usar a expressão de Zilberman, em um "manual de instruções".

Tradicionalmente, mais do que propagar um saber através do fazer literário, a literatura infantil utiliza um discurso que busca sujeitar o leitor-criança e procura ensiná-10 moralmente, fazendo com que a literatura constitua pano de fundo para a aprendizagem de outras ciências, o que sublinha a natureza coercitiva dessa prática literária. Assim, "o que pode ser opressivo num ensino não é finalmente o saber ou a cultura que ele veicula, são as formas discursivas através das quais ele é proposto." (BARTHES, 1992: 43)

Em via oposta, está o que denominamos texto do imaginário, ou seja, os textos literários nos quais o imaginário, tomando como base os textos de Lygia Bojunga Nunes, é alçado na narrativa de forma que o discurso pedagógico seja diluído no texto, que deixa de ser um discurso opressivo e principalmente didático-moralizante e passa a aliar o saber e o sabor das coisas num transbordamento da fantasia, fazendo com que os textos estejam impregnados pela inquietude de todos estes elementos: o prazer, a educação, o imaginário.

É importante ressaltar que, ao opormos texto pedagógico a texto do imaginário, não estamos afirmando que exista um texto puro, que seja somente pedagógico ou somente voltado para o imaginário, mas, sim, que há textos cuja ênfase encontra-se em um desses aspectos. Assim, em um texto pedagógico temos o imaginário, bem como em um texto do imaginário faz-se presente o pedagógico.

Segundo Iser (1996) o imaginário é uma categoria vazia que precisa ser preenchida por elementos que o mobilizem na direção da sua aparência, sendo o fictício um desses elementos. Manifestado verbalmente, o imaginário se apresentaria na organização textual; essa articulação entre fictício e imaginário é o que caracterizaria, então, o texto literário.

Ainda segundo Iser, os sonhos, os fantasmas e as alucinações, bem como as idéias e as percepções constituem experiências que, ao interagirem, também evidenciam e manifestam o imaginário. A mobilização do imaginário se desenvolve como "jogo" com as instâncias ativadoras: "Como o jogo surge de uma ativação do imaginário, orientada por finalidades, ele se torna ao mesmo tempo o lugar onde 


\section{EM TESE}

Belo Horizonte, v. 5, p. I-305, dez. 2002

transcorrem as interações mais diferentes do imaginário com suas instâncias ativadoras." (ISER, 1996: 260) 0 fictício, visto como mobilização do imaginário no texto literário, deve ser considerado como instância específica que faz com que o imaginário seja acessível para além do seu uso pragmático.

0 fictício possui, ainda como característica, uma estrutura de duplicação. No movimento de jogo, o texto transforma o mundo a ele incorporado tornando-se um "mundo especular" em que nada escapa à duplicação. No texto ficcional, o mundo retorna refratado ao mesmo tempo que busca romper com o mundo que espelha. (ISER, 1996: 327)

Um elemento importante, durante o jogo do texto, é o leitor que joga com as transformações do texto escolhendo o que e como jogar. "Como o jogo do texto é sempre mais do que mera exibição (Aufführung) daquilo que o leitor espera em virtude da atração exercida pela inacessibilidade desse 'mundo especular', isso faz com que este jogo possa ser jogado apenas individualmente pelo leitor." (ISER, 1996: 329)

0 jogo, portanto, é sempre individual, e como o texto, habitualmente, não prescreve as regras a serem seguidas, o resultado pode ser alcançado de diferentes maneiras, ou o próprio jogo pode ser jogado de diversos modos.

A leitura da obra de Lygia Bojunga, realizada neste trabalho, busca considerar este jogo que se estabelece entre texto e leitor: o leitor joga e é jogado pelo texto, brinca e adentra o universo ficcional, que assume, nesse momento, a configuração de lugar de prazer e de reunião de sabores. Modifica-se, então, a condição da criança como simples receptora dos textos, tornando-se um sujeito que participa da fabulação textual e que também constrói o texto. Paisagem é uma narrativa que bem representa esse processo:

(...) quando eu falo de Leitor eu tô querendo falar é de Li-te-ra-tu-ra, tá sacando Renata? essa coisa de escritor criar um personagem e fazer a gente acreditar nele feito coisa que toda a vida a gente conheceu o cara, ou a cara, Literatura é fazer esse personagem inventado virar um espelho pra gente, é fazer a gente ficar puto da vida se o personagem faz um troço que a gente acha besteira, mas em compensação é fazer a gente entrar numa boa se ele faz um troço que a gente também quer fazer, Literatura é o jeito que um escritor descobre pra passar isso pra gente dum jeito que é só dele, e quando um dia a gente afina com 0 jeito dum escritor inventar, com 0 jeito que é o jeito dele escrever, nesse dia a gente vira Leitor dele e quer ler tudinho que o cara ou a cara escreveu, mas quando eu digo a gente eu tô falando de Leitor feito eu, Leitor de letra maiúscula, e aí então, sabe 
Renata, a gente fica tão ligado nesse escritor que é capaz até de intuir o que que ele vai escrever... (NUNES, 1995: 35)

No percurso da leitura das obras de Lygia Bojunga, procuramos refletir como essas questões se articulam nos textos, de forma a expor os mecanismos de sua criação, que acreditamos ser mediada pela mobilização do imaginário.

$\mathrm{Na}$ obra de Lygia Bojunga o imaginário é ativado por alguns elementos recorrentes como o sonho, o devaneio, o duplo, o espelho e o próprio movimento da escrita que, ao voltar-se sobre si mesma, transforma o texto no lugar onde realidade e fantasia se interpenetram de tal forma que se torna dificil estabelecer uma linha de demarcação entre elas. 0 real faz-se linguagem e, dessa forma, constitui, ele também, um meio de acesso ao imaginário.

Nas obras da autora, salientam-se o caráter de encenação e a construção do texto ficcional como lugares de reflexos imaginários. Fazendo do exercício da escrita um exercício de encontro com o outro, Lygia Bojunga faz de suas narrativas um lugar de alçamento do imaginário e quebra a imagem do texto infantil atrelado a um ideal de criança que sufoca sua alteridade, dilui o seu reconhecimento como outro. A criança que se encena nos textos de Lygia Bojunga não é igual a todas as crianças, como também não se assemelha aos adultos. A literatura de Lygia representa um sujeito em processo de fazer-se, e lança-nos em um jogo fascinante na procura de um outro mundo: o da fantasia.

A fantasia é apenas um dos elementos que compõem a obra da autora. Seus textos encenam-se e nos encenam, sonham e nos fazem sonhar, nos expõem aos nossos próprios fantasmas e nos colocam, porque mergulhados na obra e dissolvidos nela, como seres em constante representação. Operando por meio de uma estrutura espelhada, seus textos nos permitem adentrar um lugar de imagens, sonhos, fantasmas, reflexos, alucinações que estão sempre em sintonia com uma reflexão muito comum em sua obra, que é a da própria literatura em seu processo de constituição. Por esses fatores, mobiliza-se o imaginário nos textos de Lygia Bojunga, de modo que o leitor é inserido numa narrativa que não se preocupa em edificar posições mas que celebra a palavra em suas múltiplas possibilidades.

Certamente, a análise da literatura de Lygia Bojunga não se esgota nas elaborações aqui priorizadas. Este trabalho trilha, apenas, um caminho possivel 


\section{EM TESE}

Belo Horizonte, v. 5, p. I-305, dez. 2002

para chegarmos a esses textos que encenam conflitos, perdas e dores, matérias, sim, do literário, como quer Manoel de Barros:

aquele

que não morou nunca em seus próprios abismos

nem andou em promiscuidade com seus fantasmas, não foi marcado, não será marcado. Nunca será exposto às fraquezas, ao desalento, ao amor, ao poema.

(BARROS apud CASTELO BRANCO, 1997: 76)

ABSTRACT:

The aim of this essay is to analyze the literature of Lygia Bojunga Nunes, by focusing her texts mainly as a privileged locus of production of meanings in which the imaginary and other discursive possibilities emerge and constitute the author's writing. My reflection about Nunes's work intends to check in which ways her texts would break down the pedagogical tradition of books for children, by lightening the presence of the imaginary.

KEY WORDS: imaginary, children, pedagogic, tradition, Lygia Bojunga Nunes.

REFERÊNCIAS BIBLIOGRÁFICAS

ARIĖS, Philippe. História social da criança e da família. Trad. Dora Flacksamn. 2. ed. Rio de Janeiro: Zahar, 1981. ARROYO, Leonardo. Literatura infantil brasileira. 10. ed. São Paulo: Melhoramentos, 1990.

BARTHES, Roland. Aula. 6. ed. São Paulo: Cultrix, 1992. CASTELO BRANCO, Lúcia. Ave palavras! Ave marias! Ave poesias! In: PAULINo, Graça (Org.). o jogo do livro infantil. Belo Horizonte: Dimensão, 1997.

ISER, Wolfgang. O fictício e o imaginário. Perspectivas de uma antropologia literária. Trad. Johannes Kretschmer. Rio de Janeiro: EDUERJ, 1996.

JESUALD0. A literatura infantil. Trad. James Amado. São Paulo: Cultrix, 1982.

NUNES, Lygia Bojunga. Paisagem. 2. ed. Rio de Janeiro: Agir, 1995.

SANDRONI, Laura. De Lobato a Bojunga. Rio de Janeiro: Agir, 1987. 